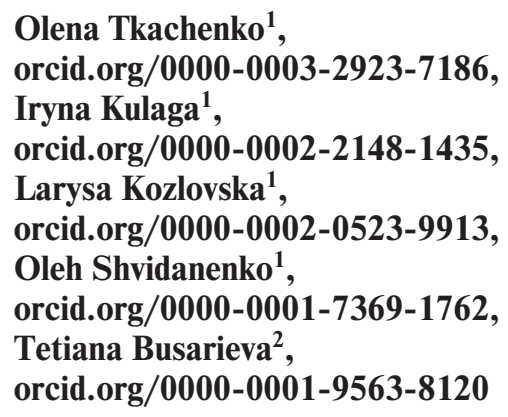

1 - Kyiv National Economic University named after Vadym Hetman, Kyiv, Ukraine

2 - Kyiv University of Trade and Economics, Kyiv, Ukraine, e-mail: sutner@ukr.net

\title{
THE IMPACT OF KNOWLEDGE COMPONENTS ON THE WORLD COMPETITIVENESS
}

Purpose. To analyze the impact of the knowledge component on the level of global competitiveness of the world.

Methodology. The methodological basis of the article is the methods and forms of scientific knowledge adopted in domestic science, such as system approaches, comparative and synthesis methods, methods of abstract logical evaluation, methods of detailing, groupings and generalizations, experts' evaluations; dynamics series, logic analysis, paired and multiple correlation techniques. Moreover, the Google Trends search engine was used, since the use of this search tool allowed drawing the following conclusions: searches for both concepts in the world and in Ukraine are substantially different: both concepts in the global space, particularly in countries with a high level of competitiveness, are hardly in demand.

Findings. Knowledge as an economic category and practical skill permeates all spheres of human life. Currently, knowledge formation is concentrated within TNCs localized in the developed countries of the world (the USA, Singapore, the EU countries, Japan, and others), which is confirmed by the level of competitiveness of the economy of these countries and high ranking of the knowledge component in it. In the overall rating of competitiveness of the influence of the components of the knowledge economy, Ukraine ranks below average, while science now barely crosses the threshold of performing a sociocultural function and begins to perform a cognitive one.

Originality. Globalization processes and technological revolution of recent decades have transformed knowledge and intellectual capital into key drivers of competitiveness in the world. We have formed and studied groups of subjective (regional and state policy, which determines the quality of economic and financial processes, as well as the management of the public sector) and objective (geographic, natural and climatic conditions, the degree of sufficiency in raw materials, infrastructure, and others) factors affecting competitiveness of countries. According to the research results, the use of this approach allows for continuous monitoring of the competitiveness level of social and economic indicators in order to identify and eliminate bottlenecks in various levels of state management.

Practical value. The authors' approach suggested is recommended to be used by scientific institutes, universities, government bodies and services for monitoring socio-economic indicators included in the groups of objective and subjective factors in order to form a holistic understanding and systematic analysis of the influence of the competitiveness of the knowledge component on different aspects of the country's social and economic life.

Keywords: knowledge, knowledge economy, world competitiveness, national economies, globalization

Introduction. In the old format model, in the process of production, natural resources are gradually depleted, while in the conditions of knowledge economy - knowledge can be infinitely generated and accumulated, and spread rapidly among all participants of the exchange with the use of modern information and communication technologies. Thus, it becomes evident that in the economy of the new format "knowledge" is a strategic resource for its development and a source of wellbeing of society, which determines the legitimacy of the term "knowledge economy". Knowledge economics is a dual term: on the one hand, it means an economic process oriented to the production and management of knowledge within economic constraints, and on the other, they refer to economics as a science based on knowledge. In the second meaning, which is more commonly used, this term refers to the use of knowledge technologies (such as knowledge development and management) to generate economic benefits and create opportunities for the developing of the national economies. In the new economy, knowledge is becoming an important and even a major indicator. For the economic development of countries, natural resources (especially oil or gas) have lost some importance, and labor and capital, as other components of the classical function of production, are directly dependent on knowl-

(C) Tkachenko Olena, Kulaga Iryna, Kozlovska Larysa, Shvidanenko Oleh, Busarieva Tetiana, 2021 edge and technology. In this approach, in addition to knowledge, attention should be paid to skills, as in the post-industrial period skills and competences in production come to the fore, which may be considered one of the main causes of the phenomenon of asymmetric transformation of the knowledge economy. That is why it is very important to understand how the development of knowledge economy affects the competitiveness of the national economies in the global world.

Literature review. The analysis of both foreign and domestic authors showed that in multinational companies the knowledge management system is one of the important assets that combines databases, documents, policies, procedures, previously unexplored knowledge, and experience of individual employees. Foreign and national scientists have realized a number of theoretical, methodological and methodical approaches to the realization of the process of the development of knowledge component, various principles and ways of analyses of the impact of the knowledge component on the development of TNC are developed. Hang C. C., Garnsey E., Ruan Y., Melnyk T., Iliashenko S. M., Soroka L., Kurkova K., Shevchuk O.A., Rudenko M. Kryvoruchko V., Awwad M., Novikova M. M., Andriushchenko K., Lavruk V., Uliganets S., Kovtun V., Matviienko H., Breznik K. and other scientists implemented the analyses of the mentioned items in their research studies.

Thus, interesting research is done by Milner B.Z. concerning the influence of knowledge component system on the 
functioning and development of the transnational corporations; scientific works by Hang C. C., Garnsey E., Ruan Y. [1], Melnyk T. [2], Iliashenko S. M. [3] refer to the set of methodological approaches, procedures, technologies and mechanisms that allow the knowledge component of the organization create additional value through the appropriate use of knowledge; Soroka L., Kurkova K. [4], Shevchuk O.A. [5], Rudenko M., Kryvoruchko V. [6], Awwad M. [7] consider the formation of knowledge institutions; works by Novikova M. M. [8], Andriushchenko K., Lavruk V., Uliganets S., Kovtun V., Matviienko H. [9], Breznik K. [10] concern the knowledge management toolkit: practical techniques for building a knowledge management system. At the same time, it is important to note that at the beginning of the $21^{s t}$ century in the conditions of development of knowledge economy it is relevant to provide efficiency of management of knowledge resources of the world competitiveness. Without denying there are significant contributions in existing developments of the chosen field of research, although another aspect should be noted that must be taken into account in the formation of the knowledge component of the world competitiveness.

Unsolved aspects of the problem. In the development of the knowledge economy, knowledge-based assets become a key factor in the development of TNCs. Accordingly, the company's ability to manage its intellectual capital is one of the defining competencies, which allows it to increase value for business owners. Thus, the prospects for the development of TNCs in the knowledge economy largely depend on its ability to manage intellectual capital. Due to the fact that the share of tangible assets in the market capitalization of companies in developed markets decreased to $16 \%$ by early 2019 (in the late 2000s it was $52 \%$ ), the relevance of the study on intellectual capital as a key factor in the success of multinational corporations will be just growing. It is obvious that in different industries the degree of influence of certain elements of intellectual capital on the performance of TNCs will be different, because even in developed markets, intellectual capital can play a diverse role in the activities of multinational corporations. That is why in the development of the knowledge economy, a necessary condition for the development of TNCs is the development of the knowledge component as one of the main components of the global competitiveness of TNCs.

Purpose. The purpose of this article is to analyze the impact of the knowledge component on the level of global competitiveness of the world.

Methods. The methodological basis of the article is the methods and forms of scientific knowledge adopted in domestic science, such as system approaches, comparative and synthesis methods, methods of abstract logical evaluation, methods of detailing, groupings and generalizations, experts' evaluations. Dynamics series, logic analysis, paired and multiple correlation techniques were applied, and the Google Trends search engine was used (since the use of this search tool resulted in the following conclusions: searches of both concepts in the world and in Ukraine have significant differences: both concepts in the global space, especially in countries with high levels of competitiveness, have virtually no demand.

Results. The core and semantic center of the new economy is knowledge, creativity, i.e. new unique ideas created by society. It is the knowledge-potential of human resources due to the generating center of the existing formation; it generates novelty, new discoveries and ideas, is able to solve complex problems productively, and, most importantly, implements them in practice decisively and dynamically. Under this approach, information and/or innovation no longer play a key role, but knowledge and human resources that generate new knowledge and put it into practice. At the same time, knowledge itself is an evaluative resource of the individual and a driving factor in the socio-economic and cultural development of the national economy. As a results of the analyses (Mil'ner, B.Z., 2010), the authors propose some systematiza- tion of the definition of knowledge, given in Table 1, where: $A$ - knowledge and information are focused on the communication aspect of the need to transfer them; $B$ - knowledge and information are determined by the degree of organization and interpretation of data; $C$ - emphasizes the connection of knowledge with human consciousness, intellectual activity, reflection and understanding of the surrounding reality; $D-$ emphasizes the connection of knowledge with a particular individual, personality; $E$ - highlights the inseparability of knowledge and information from the social, technological and other contexts [1, 2].

To study the impact of the components of the knowledge economy on the competitiveness of countries around the world, the principle of trinitarianism was applied: the influence on the example of the countries of the world which occupy the first 20 lines in the Global Competitiveness Index (GCI); investigate the mutual (direct and reverse) impact of the components of the knowledge economy and the competitiveness of the countries according to the Knowledge Economy Index (KEI) according to the European Bank for Reconstruction and Development (EBRD); due to the inaccuracy of the Digital Knowledge Economy Index (DKEI) calculation methodology was not used in the study; the influence of the components of the knowledge economy on the competitiveness of Ukraine is highlighted.

To study the impact of the knowledge economy components on the competitiveness of the world countries, which occupy the first 20 lines in the Global Competitiveness Index (GCI), from the knowledge and innovation maps of the results of the previously conducted selection, based on the pair correlations, were selected the most significant factors $-X_{3}$ (Table 2) (based on Ansoff, I., 1979).

From Table 2 it is obvious to make the conclusion that according to the results of the calculations, the multiple regression equation was obtained

$$
Y=58.7401+0.04496 X_{1}+0.2957 X_{2}+1.3979 X_{3} .
$$

Economic interpretation of model parameters: an increase in $X_{1}$ by 1 unit results in an increase in $Y$ by an average of 0.045 units; increase in $X_{2}$ by 1 unit leads to an increase in $Y$ by an average of 1.398 units. By the maximum coefficient $\beta_{2}=$ $=0.521$ we conclude that the most influential factor on $Y$ is the factor $X_{2}$.

Table 1

Classification of the definition of knowledge

\begin{tabular}{|l|c|c|c|c|c|}
\hline Authors & $A$ & $B$ & $C$ & $D$ & $E$ \\
\hline M. Polonya (1958) & & & + & + & \\
\hline F. Machlup (1962) & + & & & & \\
\hline J. Bell (1970) & + & & + & & \\
\hline M. Pora (1977) & + & & & & \\
\hline Russian philosophers (1990 th years) & & & & & + \\
\hline K. Wing (1993) & & + & + & & \\
\hline P. Helson, P. Romer (1996) & & & + & & \\
\hline T. Stuard (1997) & & + & & & \\
\hline J. Hodson (2001) & & + & & & \\
\hline T. P. Nicolaeva (2001) & + & & + & + & \\
\hline B. Z. Mil'ner (2003) & & + & & & \\
\hline T. Gavrilova, V. Horoshevskyi (2003) & & & + & & \\
\hline V. V. Labotskyi (2006) & + & & + & & \\
\hline V. A. Dresvyannikov (2010) & + & + & & + & \\
\hline T. Andreeva, T. Gutnikova (2010) & & & + & + & \\
\hline
\end{tabular}


Output matrix to determine the impact of knowledge economy components on global competitiveness

\begin{tabular}{|c|c|c|c|c|}
\hline $\begin{array}{c}\text { Top-20 countries in } \\
\text { the Global } \\
\text { Competitive Index }\end{array}$ & 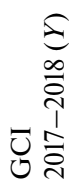 & 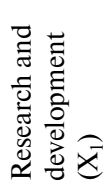 & 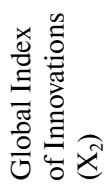 & 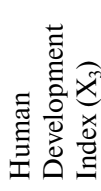 \\
\hline United States & 85.6 & 96.1 & 61.40 & 0.924 \\
\hline Singapore & 83.5 & 70.9 & 58.69 & 0.932 \\
\hline Germany & 82.8 & 99.0 & 58.39 & 0.936 \\
\hline Switzerland & 82.6 & 82.6 & 67.69 & 0.944 \\
\hline Japan & 82.5 & 100.0 & 54.72 & 0.909 \\
\hline Netherlands & 82.4 & 75.9 & 63.36 & 0.931 \\
\hline Hong Kong SAR & 82.3 & 49.2 & 53.88 & 0.933 \\
\hline United Kingdom & 82.0 & 85.4 & 60.89 & 0.922 \\
\hline Sweden & 81.7 & 81.2 & 63.82 & 0.933 \\
\hline Denmark & 80.6 & 77.7 & 58.70 & 0.929 \\
\hline Finland & 80.3 & 77.0 & 58.49 & 0.920 \\
\hline Canada & 79.9 & 80.3 & 53.65 & 0.926 \\
\hline Taiwan, China & 79.3 & 84.2 & 52.54 & 0.502 \\
\hline Australia & 78.9 & 78.8 & 51.87 & 0.939 \\
\hline Korea, Rep. & 78.8 & 91.0 & 57.70 & 0.903 \\
\hline Norway & 78.2 & 65.5 & 53.40 & 0.953 \\
\hline France & 78.0 & 91.5 & 54.18 & 0.901 \\
\hline New Zealand & 77.5 & 53.1 & 52.87 & 0.917 \\
\hline Luxembourg & 76.6 & 51.3 & 56.40 & 0.904 \\
\hline Israel & 76.6 & 76.7 & 53.88 & 0.903 \\
\hline
\end{tabular}

In other words, the level of competitiveness of the TOP-20 competitive countries in the context of the paradigm of the impact of the knowledge economy serves the greatest dependence on innovation, the embodiment of which determines their leading position in the relevant global ranking.

The positive, but not significant, impact of $R \& D$ spending is indicative, since the financial support for the development of the knowledge economy in the countries studied is already subject to marginal utility theory, meaning that each additional unit of investment does not lead to a significant increase in competitiveness.

At the same time, the return on investment in overall human development is direct evidence of the so-called "background" importance of spending on education and science as a common factor in the formation of a knowledge economy culture, since the even correlation coefficient is quite low (0.172), which in this case can be interpreted as providing competitiveness of the country at the expense of the general level of human development.

The lack of complete, overlapping data on the values of the Global Competitiveness Index $(Y)$ and the Knowledge Economy Index $(X)$, unfortunately, makes it impossible to study their interdependence (Table 3) [3].

Analyzing Table 3 it is necessary to mention that the dependence of $Y$ on $X$ is studied. In the specification step, a pairwise linear regression was chosen. It estimated its least squares parameters. The linear regression equation looks like this

$$
Y=69.783+1.227 X \text {. }
$$

The coefficients of the linear regression equation can be given an economic sense. The regression coefficient $b=1.227$
Output matrix to determine the impact of the Knowledge Economy Index on the Global Competitiveness Index of the World

\begin{tabular}{|c|c|}
\hline $\begin{array}{c}\text { GCI } \\
2017-2018(\boldsymbol{Y})\end{array}$ & $\begin{array}{l}\text { Knowledge Economy Index (KEI) } \\
2012(\mathrm{X})\end{array}$ \\
\hline 85.6 & 8.77 \\
\hline 83.5 & 8.26 \\
\hline 82.8 & 8.90 \\
\hline 82.6 & 8.87 \\
\hline 82.5 & 8.28 \\
\hline 82.4 & 9.11 \\
\hline 82.3 & 8.52 \\
\hline 82.0 & 8.76 \\
\hline 81.7 & 9.43 \\
\hline 80.6 & 9.16 \\
\hline 80.3 & 9.33 \\
\hline 79.9 & 8.92 \\
\hline 79.3 & 8.77 \\
\hline 78.9 & 8.88 \\
\hline 78.8 & 7.97 \\
\hline 78.2 & 9.11 \\
\hline 78.0 & 8.21 \\
\hline 77.5 & 8.97 \\
\hline 76.6 & 8.37 \\
\hline 76.6 & 8.14 \\
\hline
\end{tabular}

shows the average change in the resultant index (in units of $y$ ) with increasing or decreasing values of factor $x$ per unit of measurement. A possible economic interpretation of the model parameters is that with an increase in KEI by 1 unit, GCI increases by an average of 1.227 . The coefficient $a=69.783$ formally shows the predicted level of $y$, but only if $x=0$ is close to the sample value.

The statistical significance of the equation is verified using the Fisher's determination coefficient and criterion. It is established that in the study situation $4.21 \%$ of the total variability of $Y$ is explained by the change in $X$. In contrast to the previous part of the study, data on ECIs for the most competitive EBRD countries exist [4, 5] (Table 4).

The study on forward and inverse dependencies (pairwise linear regression) yielded the following results. Economic interpretation of model parameters means that the competitiveness of the studied countries depends on the development of their knowledge economy in this way: increase in KEI by 1 unit leads to an increase in $Y$ by an average of 1.227 units. The linear equation has the form

$$
Y(G C I)=+69.783+1.227 X(K E I) .
$$

The coefficients of the linear regression equation can be given an economic sense. The regression coefficient $b=1.227$ shows the average change in the resultant index (in units of $y$ ) with increasing or decreasing values of factor $x$ per unit of measurement. In this example, an increase in $1 y$ increases by an average of 1.227 .

The coefficient $a=69.783$ formally shows the predicted level of $y$, but only if $x=0$ is close to the sample values. At the same time, there is an inverse relationship (calculation method - similar to the previous one), i. e. the competitiveness of a country affects the level of development of its knowledge economy 
Table 4

Source matrix for determining the impact of the knowledge economy for competitiveness of countries (according to EBRD KEI)

\begin{tabular}{|l|c|c|}
\hline \multicolumn{1}{|c|}{ TOP -20} & $\begin{array}{c}\text { Global Competitiveness } \\
\text { Index }\end{array}$ & $\begin{array}{c}\text { Knowledge } \\
\text { Economy Index }\end{array}$ \\
\hline Azerbaijan & 4.69 & 4.56 \\
\hline Armenia & 4.15 & 4.51 \\
\hline Bulgaria & 4.46 & 5.18 \\
\hline Croatia & 4.19 & 5.62 \\
\hline Cyprus & 4.30 & 5.82 \\
\hline Estonia & 4.85 & 6.82 \\
\hline Georgia & 4.28 & 4.97 \\
\hline Greece & 4.02 & 5.25 \\
\hline Hungary & 4.33 & 5.33 \\
\hline Kazakhstan & 4.35 & 4.85 \\
\hline Latvia & 4.40 & 5.88 \\
\hline Lithuania & 4.58 & 6.03 \\
\hline Montenegro & 4.15 & 5.04 \\
\hline Poland & 4.59 & 5.63 \\
\hline Romania & 4.28 & 5.01 \\
\hline Russia & 4.64 & 4.93 \\
\hline Serbia & 4.14 & 5.13 \\
\hline Slovak Republic & 4.33 & 5.40 \\
\hline Slovenia & 4.48 & 6.65 \\
\hline Turkey & 4.42 & 4.60 \\
\hline
\end{tabular}

$$
Y(K E I)=1.1529 X(G C I)+0.3091,
$$

that is, the development of the knowledge economy from the level of competitiveness of the country also exists and is as follows: increase in GCI by 1 unit results in an increase in the KEI by an average of 0.3091 units. In both cases, the dependencies are strong and reliable $[6,7]$.

Analyzing Ukraine, it is necessary to mention that in the World Competitiveness Rating, which is compiled annually by the International Institute for Management Development in Switzerland (IIMD), Ukraine has risen by 5 positions and ranks 54. Our country is between Slovakia and Peru. Among the post-Soviet countries, Lithuania (29), Kazakhstan (34) and Estonia (35) occupy the highest positions. Overall, there are 63 countries. Singapore came first in 2019, while the US ranked third (this country is now in third place). Hong Kong is in second place. Singapore's rise to the forefront was driven by advanced technological infrastructure, the availability of skilled labor, favorable immigration laws and effective ways of starting new businesses. Hong Kong was ranked second in terms of good tax and business policies and business access to finance. Instead, the competitiveness of the largest economy in the world, the US, has been plagued by rising fuel prices, weaker high-tech exports, and fluctuations in the value of the dollar. Venezuela ranks last in the ranking of competitiveness. Compilers point to high inflation in the country, poor credit access and a weak economy $[8,9]$.

In the global economic competitiveness ranking of 2018, which is ranked annually by various indicators, the World Economic Forum (WEF), together with the Eurasian Competitiveness Institute and Strategy Partners, Ukraine ranked $83^{\text {rd }}$ out of 140 countries. Before that, it was $89^{\text {th }}$ among 135 countries. The rating drafters noted that in Ukraine there are poorly developed institutions, extremely unstable financial system and macroeconomic indicators.
To carry out this part of the study, the influence of the components of the knowledge economy on the competitiveness of Ukraine is highlighted. For this purpose, the GCI isolated quantitative expression of the Inclusive Development Index was considered, which is given the status of a dependent value, which is the driving force of competitiveness (Table 5) $[10,11]$

It can be assumed that its critical mass, that is, a notional amount, does not translate into quality and does not focus on promoting the development of a knowledge economy (characteristics of Ukraine's migration security may also be tangible explanations). Whereas the nonlinear (degree) paired correlation dependence of Ukraine's competitiveness on the values of the Education Index showed that the values of competitiveness by $43.75 \%$ vary precisely from the change in this index, and its change by $1 \%$ may increase the country's competitiveness by an average of $4.054 \%$, which is direct evidence of the validity of additional funding for national education (despite the fact that the specified quality of education index is not taken into account) $[8,12]$.

Choosing the components of the knowledge economy in this part of the study also deliberately avoided the study on the impact of spending on research. First, this is due to differences in their content in domestic and world practice. Secondly, due to the fact that the world practice has shown that depending on the share of GDP allocated for research, science can perform three functions: sociocultural - provided that the indicator of the intensity of GDP does not exceed $0.4 \%$, cognitive - from 0.4 to $0.9 \%$, economic - at exceeding the mark $0.9 \%$. This means that the results of scientific achievements will have an impact on the development of the national economy when the share of expenditures on research and development as a percentage of GDP is greater than $0.9 \%$. So, in Ukraine, science is now barely crossing the threshold of fulfilling a socio-cultural function and beginning to fulfill a cognitive one [13, 14].

For further conclusions it is important to notice that inclusive Development Index will be mentioned as $Y$, innovation

Table 5

Data matrix for determining the impact of knowledge economy components on Ukraine's competitiveness

\begin{tabular}{|c|c|c|c|c|c|c|}
\hline Years & 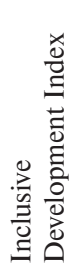 & 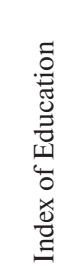 & 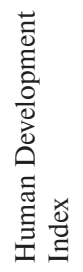 & 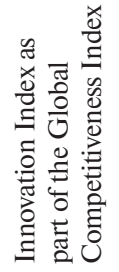 & 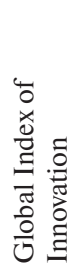 & 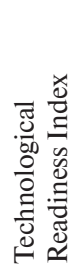 \\
\hline 2004-2005 & 3.27 & 0.755 & 0.706 & & & \\
\hline 2005-2006 & 3.30 & 0.776 & 0.715 & & & \\
\hline 2006-2007 & 3.89 & 0.781 & 0.721 & & & \\
\hline $2007-2008$ & 3.98 & 0.784 & 0.729 & 3.2 & 2.24 & 2.7 \\
\hline 2008-2009 & 4.09 & 0.786 & 0.733 & 3.4 & 2.77 & 3.4 \\
\hline 2009-2010 & 3.95 & 0.787 & 0.727 & 3.2 & 3.06 & 3.4 \\
\hline 2010-2011 & 3.90 & 0.788 & 0.733 & 3.1 & 3.06 & 3.4 \\
\hline $2011-2012$ & 4.00 & 0.787 & 0.738 & 3.1 & 35.01 & 3.5 \\
\hline $2012-2013$ & 4.14 & 0.791 & 0,743 & 3.2 & 36.10 & 3.6 \\
\hline $2013-2014$ & 4.05 & 0.796 & 0,745 & 3.0 & 35.78 & 3.3 \\
\hline 2014-2015 & 4.14 & 0.794 & 0.748 & 3.2 & 36.26 & 3.5 \\
\hline $2015-2016$ & 4.03 & 0.794 & 0.743 & 3.4 & 36.50 & 3.4 \\
\hline 2016-2017 & 4.00 & 0.794 & 0.746 & 3.4 & 35.72 & 3.6 \\
\hline $2017-2018$ & 3.40 & 0.794 & 0.751 & 3.4 & 37.62 & 3.8 \\
\hline
\end{tabular}


Index as part of the Global Competitiveness Index $-X_{1}$, global index of innovations $-X_{2}$, technological readiness index $-X_{3}$.

Analyzing Table 5, it is necessary to mention that the regression equation (estimation of regression equation): $Y=$ $=5.7084-0.2699 X_{1}+0.00193 X_{2}-0.2663 X_{3}$. As a result of the calculations, the multiple regression equation was obtained: $Y=5.7084-0.2699 X_{1}+0.00193 X_{2}-0.2663 X_{3}$. Economic interpretation of model parameters is possible: increase in $X_{1}$ by 1 unit of change results in a $Y$ decrease by 0.27 units on average; increase in $X_{2}$ by 1 unit results in an increase in $Y$ by an average of 0.00193 units; increase in $X_{3}$ by 1 unit leads to a decrease in $Y$ by an average of 0.266 units. Obviously, to explain the backlash of $X_{3}$ on the Inclusive Development Index can be low technological readiness or unpreparedness $[15,16]$.

Conclusion. The unevenness of the country's development is conditioned by objective (geographical and natural and climatic conditions; degree of supply of raw materials, infrastructure prerequisites for economic development, and others) and subjective factors (regional government policy that determines the quality of economic processes and financial and budgetary sphere management). It is the imbalance in economic and social aspects that is the main indicator of the weakening of the efficiency and effectiveness of the functioning of different levels of public administration in order to improve the indicators of growth of the level of knowledge economy development.

To conclude the mentioned above information, it is necessary to mention that in modern society there are radical changes that lead to the dominance of knowledge as a factor of social development. At the same time, methodological approaches that note the existence of an information or post-industrial society were based on the presumption of equality of opportunity arising in the conditions of free circulation of information. As practice shows, the formation of a system of information technology that determines the structure of resource allocation at the current stage of civilizational development, does not lead to equality of opportunity, but reproduces the factors of inequality at a new stage of development. Therefore, the formation of the paradigm of development of the knowledge component is a methodological innovation designed to analyze the processes occurring in the modern world, give them a socio-philosophical assessment and identify prospects for further development.

\section{References.}

1. Hang, C. C., Garnsey, E., \& Ruan, Y. (2015). Opportunities for disruption. Technovation, 39-40, 88-90. https://doi. org/10.1016/J.TECHNOVATION.2014.11.005.

2. Melnyk, T. (2018). Ukraine and Its Future in a Globalised International Community. Ukrainian Policymaker, 3, 17-28. https://doi.org/10.29202/up/3/3.

3. Iliashenko, S. M. (2016). Innovative development: marketing and knowledge management. Sumy: Disa Plus LLC.

4. Soroka, L., \& Kurkova, K. (2019). Artificial Intelligence and Space Technologies: Legal, Ethical and Technological Issues. Advanced Space Law, 3, 131-139. https://doi. org/10.29202/asl/2019/3/11.

5. Shevchuk, O. A. (2018). System-synergetic approach to providing dynamic stability of enterprises based business leadership. Economic bulletin of NTUU "KPI", 15, 199-207.

6. Rudenko, M., \& Kryvoruchko, V. (2016). Knowledge management as a competitive advantage of enterprise. Ekonomika ta derzhava, (4), 74-78.

7. Awwad, M. (2018). Influences of Frege's Predicate Logic on Some Computational Models. Future Human Image, 9, 5-19. https://doi.org/10.29202/fhi/9/1.

8. Novikova, M. M. (2017). Concept genesis "intellectual capital of the company". Market Infrastructure, 5, 108-112.

9. Andriushchenko, K., Lavruk, V., Uliganets, S., Kovtun, V., \& Matviienko, H. (2019). Reputation Risk Management Companies Based on Competence Approach. TEM Journal, 8(2), 516-524. https://doi.org/10.18421/TEM82-27.
10. Breznik, K. (2018). Knowledge Management - from its Inception to the Innovation Linkage. Procedia - Social and Behavioral Sciences, 238, 141-148. https://doi.org/10.1016/j. sbspro.2018.03.017.

11. Yi, Y., Meng, M., \& Wei, Z. (2017). Bottom-up learning, strategic flexibility and strategicchange. Journal of Organizational Change Management, 30(2), 161-183. https://doi. org/10.1108/JOCM-12-2015-024.

12. Baharun, R., Jing Mi, T., Streimikiene, D., Mardani, A., Shakeel, J., \& Nitsenko, V. (2019). Innovation in healthcare performance among private brand's healthcare services in small and medium-sized enterprises (SMEs). Acta Polytechnica Hungarica, 16(5), 151-172. https://doi.org/10.12700/APH.16.5.2019.5.9. 13. Tretyak, O.A., \& Klimanov, D.E. (2016). New Approach to Business Model Analysis. Russian Management Journal, 14(1), 115-130.

14. Yatsenko, O., Nitsenko, V., Mardani, A., Streimikiene, S., \& Tananaiko, T. (2019). Global Risks of Trade and Economic Cooperation of Ukraine with Countries of the Northern American Region. Montenegrin Journal of Economics, 15(3), 217-225. https://doi.org/10.14254/1800-5845/2019.15-3.16. 15. OECD (2016). Enabling China's Transition towards a Knowledge-based Economy: (Chinese version). Paris: OECD Publishing. https://doi.org/10.1787/9789264266858-zh.

16. Kholiavko, N., Popova, L., Marych, M., Hanzhurenko, I., Koliadenko, S., \& Nitsenko, V. (2020). Comprehensive methodological approach to estimating the research component influence on the information economy development. Naukovyi Visnyk Natsionalnoho Hirnychoho Universytetu, (4), 192199. https://doi.org/10.33271/nvngu/2020-4/192.

\section{Вплив компонента знань на глобальну конкурентоспроможність}

\section{О. В. Ткаченко ${ }^{1}$, І. В. Кулага ${ }^{1}$, Л. С. Козловська ${ }^{1}$, О. А. Швиданенко ${ }^{1}$, Т. Г. Бусарєва ${ }^{2}$}

1 - Київський національний економічний університет імені Вадима Гетьмана, м. Київ, Україна

2 - Київський національний торговельно-економічний університет, м. Київ, Україна, e-mail: sutner@ukr.net

Мета. Дослідити вплив компонента знань на рівень глобальної конкурентоспроможності світу.

Методика. Методологічною основою роботи є методи і форми наукового пізнання, прийняті у вітчизняній науці, такі як; системні підходи; порівняльно-синтезуюючі методи; методи абстрактно-логічного оцінювання; методи деталізації, групування та узагальнення; експертні оцінки; динамічні ряди; логічний аналіз; методи парної і множинної кореляції. Також була використана пошукова система Google Trends, оскільки використання цього пошукового інструменту дозволило зробити наступні висновки: пошуки обох концептів у світі і в Україні мають суттєві відмінності: обидва концепти у глобальному просторі, особливо у країнах з високим рівнем конкурентоспроможності, практично не затребувані.

Результати. Знання як економічна категорія та практичне вміння пронизує всі сфери життєдіяльності людини. На поточний момент формування знань сконцентровано в руках ТНК, зосереджених у розвинених країнах світу (США, Сінгапур, країни ЄС, Японія та ін.), що підтверджується рівнем конкурентоспроможності економік цих країн і високим місцем компонента знань в ній. Україна, у загальному рейтингу конкурентоспроможності впливу компонентів економіки знань, займає положення нижче середнього, а наука зараз ледь переступає поріг виконання соціокультурної функції й починає виконувати когнітивну.

Наукова новизна. Процеси глобалізації та технологічна революція останніх десятиліть перетворили знання та 
інтелектуальний капітал у ключові фактори конкурентоспроможності у світі. Нами сформовані й досліджені групи суб'єктивних (регіональна й державна політика, що визначає якість економічних і фінансових процесів, а також управління бюджетною сферою) і об’єктивних (географічні, природно-кліматичні умови, ступінь забезпеченості сировиною, інфраструктура тощо) факторів, що впливають на конкурентоспроможність країн. Як показали результати досліджень, використання даного підходу дозволяє вести постійний моніторинг рівня конкурентоспроможності соціальних і економічних показників з метою виявлення та усунення вузьких місць у різних рівнях державного управління.

Практична значимість. Запропонований авторський підхід рекомендується використовувати науковим інститутам, університетам, органам державного управління та службам моніторингу соціально-економічних індикаторів, включених до груп об'єктивних і суб'єктивних факторів, з метою формування цілісного розуміння й системного аналізу впливу конкурентоспроможності компонента знань на різні сторони соціально-економічного життя країни.

Ключові слова: знання, економіка знань, світова конкурентоспроможність, національні економіки, глобалізація

\section{Влияния компонента знаний на мировую конкурентоспособность}

\section{О. В. Ткаченко ${ }^{1}$, И. В. Кулага ${ }^{1}$, Л. С. Козловская ${ }^{1}$,} О. А. Швиданенко ${ }^{1}$, Т. Г. Бусарева ${ }^{2}$

1 - Киевский национальный экономический университет имени Вадима Гетьмана, г. Киев, Украина,

2 - Киевский национальный торгово-экономический университет, г. Киев, Украина, e-mail: sutner@ukr.net

Цель. Исследовать влияние компонента знаний на уровень глобальной конкурентоспособности мира.

Методика. Методологической основой работы являются методы и формы научного познания, принятые в отечественной науке, такие как: системные подходы; сравнительно-синтезирующие методы; методы абстрактно-логического оценивания; методы детализации, группировки и обобщения; экспертные оценки; динамические ряды; логический анализ; методы парной и множественной корреляции. Также использовалась поисковая система Google Trends, поскольку использование этого поискового инструмента позволило сделать следу- ющие выводы: поиски обоих концептов в мире и в Украине имеют существенные различия: оба концепта в глобальном пространстве, особенно в странах с высоким уровнем конкурентоспособности, практически не востребованы.

Результаты. Знания как экономическая категория и практическое умение пронизывает все сферы жизнедеятельности человека. На текущий момент формирование знаний сконцентрировано в руках ТНК, сосредоточенных в развитых странах мира (США, Сингапур, страны ЕС, Япония и др.), что подтверждается уровнем конкурентоспособности экономик этих стран и высоким местом компонента знаний в ней. Украина, в общем рейтинге конкурентоспособности влияния компонентов экономики знаний, занимает положение ниже среднего, а наука сейчас едва переступает порог выполнения социокультурной функции и начинает выполнять когнитивную.

Научная новизна. Процессы глобализации и технологическая революция последних десятилетий превратили знания и интеллектуальный капитал в ключевые факторы конкурентоспособности в мире. Нами сформированы и исследованы группы субъективных (региональная и государственная политика, определяющая качество экономических и финансовых процессов, а также управление бюджетной сферой) и объективных (географические, природно-климатические условия, степень обеспеченности сырьем, инфраструктура т.д.) факторов, влияющих на конкурентоспособность стран. Как показали результаты исследований, использование данного подхода позволяет вести постоянный мониторинг уровня конкурентоспособности социальных и экономических показателей с целью выявления и устранения узких мест в различных уровнях государственного управления.

Практическая значимость. Предложенный авторский подход рекомендуется использовать научным институтам, университетам, органам государственного управления и службам мониторинга социально-экономических индикаторов, включенных в группы объективных и субъективных факторов, с целью формирования целостного понимания и системного анализа влияния конкурентоспособности компонента знаний на разные стороны социально-экономической жизни страны.

Ключевые слова: знания, экономика знаний, мировая конкурентоспособность, национальные экономики, глобализация

Recommended for publication by V.I. Kyrylenko, Doctor of Economic Sciences. The manuscript was submitted 23.08.20. 